legislation, Transworld Airlines is not much better off, while Eastern Airlines finally went out of business two weeks ago when its equipment was auctioned off at half-adozen hub airports in the United States. The standard explanation is usually given as one word: deregulation, which is a reference to the scrapping by the Reagan administration of the practice by which civil servants used to decide which airlines could fly between which pairs of cities and, often, what fares they could charge. Critics of deregulation argue that the outcome has simply been to replace two once-dominant airlines (PanAm and TWA) by two others (United and American). But that is an overfacile and even irrelevant observation.

Elsewhere in the world, airlines are in trouble for reasons that are almost the opposite: too much regulation. Even in Europe and Japan, governments retain a financial stake in (and responsibility for) national airlines, which is a reminder of how an airline and a television station were once the symbols of nationhood. Elsewhere in the world, outright ownership is the rule. And even where deregulation has been given a chance, the old ways persist. The chairman of the Federal Aviation Authority has been musing in public that US legislation might be altered to let foreign interests control up to 49 per cent of the stock of US airlines without explaining why 51 per cent (or even 100 per cent) would be improper. In Britain, meanwhile, the government has declined after nearly three months to decide whether PanAm and TWA could transfer their rights to operate from London's Heathrow Airport (to United and American respectively).

These are disgraceful ways of depriving the world of the benefits of a marvellous technology whose application is hamstrung by three awkward economic characteristics demand for travel is seasonal, the marginal costs of carrying extra people are low and overall capital costs are high. Most airlines would be more successful than at present if they were truly international, if the regulators allowed them to discount the fares they charge to frequent travellers (instead of to off-peak travellers) and if the regulatory authorities required of them not merely vigilance on safety but on balance sheets as well. (If capital ratios are required of banks, why not of airlines?) Otherwise, if artificial national subsidies were swept away, so might safely be the surviving regulations.

\section{Indian reputations}

The suspension of an infamous Indian palaeontologist does not mean that the rest of India must hang its head.

THERE are two things to say about the decision by the Panjab University of Chandighar that Professor V. J. Gupta, the palaeontologist, should be suspended from his post (see page 645): first, it is the right decision and, second, it should have been taken a year ago. After all, nearly two years have now passed since professional criticisms of Gupta's published work were given wide NATURE - VOL $349 \cdot 21$ FEBRUARY 1991 publicity. Even after allowing for the instinctive inclination of academic institutions to defend their favourite sons, Chandighar seems to have let loyalty get the better of good judgement by failing to give the allegations against Gupta the weight that they manifestly deserved. Even as recently as last month, it seemed ready to supplement the damning reports of the two inquiries so far undertaken by a third - that of a proposed inquiry by a retired high court judge. Its hand seems to have been forced only by the publication of the gist of the report from the Geological Society of India.

The lesson that the University of Chandighar should have learned from elsewhere is that allegations of malpractice, while fortunately rare, must be dealt with quickly and decisively. Moreover, there are the strongest reasons why an accused's own institution should take the initiative in the investigation of cogent complaints, however they may arise. Not the least of these is that academic institutions failing to take on such admittedly distasteful tasks hazard their claim to govern themselves autonomously.

But may not the allegations against Gupta, suggesting that he had salted Himalayan strata with often banal fossil specimens from elsewhere, have been a pack of lies? That belief, to which the university has clung for too long, would have been the easier to sustain if Gupta had proved able to respond to the criticism of his work by making his research material available for responsible inspection. Instead, he has blustered that the allegedly misattributed fossils were indeed found in the strata in which their discovery was originally reported (see Nature 338, 613; 1989). That does not in itself imply that Gupta's position is untenable, but it did require that the university should have taken steps to see that Gupta's fossils were made accessible - and that it should have suspended him if he disagreed.

What does all this imply for the reputation of Indian science? Is it all tarred with the same brush? Many in India fear that people elsewhere will jump to that conclusion, but it would be incorrect. As the world knows, much research in India is excellent by accepted international standards. As everywhere, much of it is also humdrum, but honest. India's difficulty is that it is a society in rapid transition, where the traditions of what constitutes proof of discovery developed since the Second World War coexist with those from earlier times. Some institutions have not yet shaken off the notion that the director of a laboratory or the head of a department is by definition a big shot in every way, entitled to keep his junior colleagues in thrall. (This journal will make it its business to see what happens now to Gupta's ex-colleagues at Chandighar, and will protest if they are victimized.) There is also a somewhat mystical hankering after theories of everything. But there is no reason why people elsewhere should be misled by these circumstances, but, rather, every reason why they should, with discrimination, honour good Indian science for what it is - an important contribution to all our understanding. 